\title{
PENERAPAN APLIKASI MANAJEMEN LABORATORIUM PADA DINAS PERTANIAN DAN PERIKANAN KOTA BANJARMASIN
}

\author{
Ade Davy Wiranata ${ }^{1}$, Hafid Sulistyo Rachman ${ }^{2}$, Yazid Saifudin ${ }^{3}$ \\ ${ }^{1}$ Teknik Informatika, ${ }^{2,3} \mathrm{Ilmu}$ Komputer \\ ${ }^{1}$ Universitas Muhammadiyah Prof Dr Hamka, ${ }^{2,3}$ Universitas Budi Luhur Jakarta, Indonesia \\ Correspondence email: adedavy@uhamka.ac.id
}

Article history: Submission date: Okt 26, 2020 Revised date: Nov 15, 2020 Accepted date: Nov 24, 2020

\begin{abstract}
The Banjarmasin City Agriculture and Fisheries Office in providing innovation desperately needs a management that can manage an organization to be more structured with the specified procedures. The problem in this study is that there is no application program for processing data. The purpose of this research is to create and implement management applications that can help facilitate and accelerate the management of laboratory data at the Banjarmasin City Agriculture and Fisheries Office. The data collection methods used are interviews, observations, and review literature while the research methods used use SDLC waterfall. The result of this research is that the application that has been created can be used to facilitate and speed up the processing of data at the Office of Agriculture and Fisheries Banjarmasin City.
\end{abstract}

Keywords: Application, Management, Laboratory, SDLC.

\begin{abstract}
ABSTRAK
Dinas Pertanian dan Perikanan Kota Banjarmasin dalam memberikan inovasi sangat memerlukan suatu manajemen yang dapat mengelola sebuah organisasi menjadi lebih terstruktur dengan prosedur yang telah ditentukan. Permasalahan dalam penelitian ini adalah belum adanya sebuah program aplikasi untuk melakukan pengolahan data. Tujuan dari penelitian ini untuk membuat dan menerapan aplikasi manajemen yang dapat membantu mempermudah dan mempercepat dalam pengelolaan data laboratorium pada Dinas Pertanian dan Perikanan Kota Banjarmasin. Metode pengumpulan data yang digunakan adalah wawancara, observasi, dan literature review sedangkan metode penelitian yang digunakan menggunakan SDLC Waterfall. Hasil dari penelitian ini adalah aplikasi yang telah dibuat dapat digunakan untuk mempermudah dan mempercepat pengolahan data pada Dinas Pertanian dan Perikanan Kota Banjarmasin.
\end{abstract}

Kata Kunci: Aplikasi, Manajemen, Laboratorium, SDLC.

\section{PENDAHULUAN}

Pada organisasi baik itu bidang jasa, dagang atau instansi tidak akan lepas dari kegiatan pengolahan data, baik secara manual ataupun dengan cara elektronik. Pengolahan data, bukan sekedar kegiatan tulis menulis, menyimpan berkas. Pengolahan data merupakan suatu hal rutinitas organisasi sehingga perlu dibudayakan dengan baik dan benar supaya menghasilkan suatu informasi yang akurat (Sani \& Wiliani, 2019).
Informasi yang cepat dan akurat dalam pengambilan keputusan yang tepat perlu dikembangkan sistem pengolahan data dengan baik. Karena itu harus diperlukan alat yang dapat melakukan tugas-tugas tersebut secara cepat dan akurat yaitu komputer yang mempunyai keunggulan dalam pemrosesan data baik yang harus diolah, disimpan, disajikan, dianalisa ketepatannya dan kecepatan hasil yang dicapai. 
kelebihan lain dari komputer yaitu dapat menangani ratusan data setiap harinya dan dapat memproses data secara cepat dan mengurangi resiko kesalahan dalam hal pemprosesan data (Wiranata et al., 2020).

Permasalahan di Laboratorium Dinas Pertanian dan Perikanan Kota Banjarmasin adalah belum adanya sebuah program aplikasi untuk melakukan pengolahan data. Saat ini memang sudah menggunakan komputer sebagai sarana untuk mengerjakan kegiatan-kegiatan yang berkaitan dengan administrasi maupun manajemen. Namun masih sebatas untuk membuat jadwal kunjungan, daftar absensi petugas, pendataan inventaris laboratorium dan membuat laporan dengan menggunakan aplikasi Microsoft Office seperti word dan excel sehingga mengakibatkan keterlambatan dalam pemprosesan data dan menyulitkan dalam pencarian informasi atau data yang diinginkan.

Tujuan dari penelitian ini untuk membuat dan menerapan aplikasi manajemen yang dapat membantu mempermudah dan mempercepat dalam pengelolaan data laboratorium pada Dinas Pertanian dan Perikanan Kota Banjarmasin (Pusparini et al., 2020).

Sistem yang menggunakan sebuah program aplikasi diharapkan dapat meningkatkan kecepatan dalam pemprosesan data dan menjadikan lebih efesiensi dalam mencari informasi yang diinginkan. Dalam pembuatan aplikasi ini, penulis menggunakan bahasa pemograman Borland Delphi dan MySQL sebagai databasenya.

\section{METODE PENELITIAN}

Metode pengumpulan data yang di lakukan oleh penulis adalah sebagai berikut : (Budiyantara et al., 2020).

\section{Wawancara}

Mengumpulkan data-data dengan cara bertanya kepada pegawai atau stap di instansi tersebut yang di anggap mengerti terhadap data-data yang berhubungan dengan penyusunan penelitian ini. Teknik pengumpulan data secara wawancara merupakan proses komunikasi yang sangat menentukan dalam proses penelitian, dengan wawancara data yang diperoleh akan lebih mendalam, karena mampu menggali pemikiran atau pendapat secara detail. Dalam pelaksanaan wawancara diperlukakan keterampilan dari seorang peneliti dalam berkomunikasi dengan respoden (Galih Surono, 2020).

\section{Observasi}

Mengumpulkan data dengan cara turun langsung kelapangan dan melakukan pencatatan secara sistematik. Saat melakukan obervasi penulis mengamati secara langsung proses pencatatan data alat Laboratorium di
Dinas Pertanian dan Perikanan Kota Banjarmasin. Observasi dapat dilakukan dengan dua cara, yaitu observasi partisipasi dan non-partisipasi. Observasi partisipasi di lakukan apabila peneliti ikut terlibat secara langsung, sehingga menjadi bagian dari kelompok yang diteliti. Observasi non partisipan adalah observasi yang dilakukan dimana peneliti tidak menyatu dengan yang diteliti, peneliti hanya sekedar sebagai pengamat.

\section{Literatur}

Penyusun memperoleh data dengan cara mendownload jurnal-jurnal yang ada di internet kemudian mempelajarinya guna mencari data yang diinginkan.

Menurut (Association, 1983), literatur adalah bahan bacaan yang digunakan dalam berbagai aktivitas baik secara intelektual maupun reaksi.

\section{Metode Penelitian} Waterfall.

$$
\text { Metode penelitian yang digunakan adalah }
$$

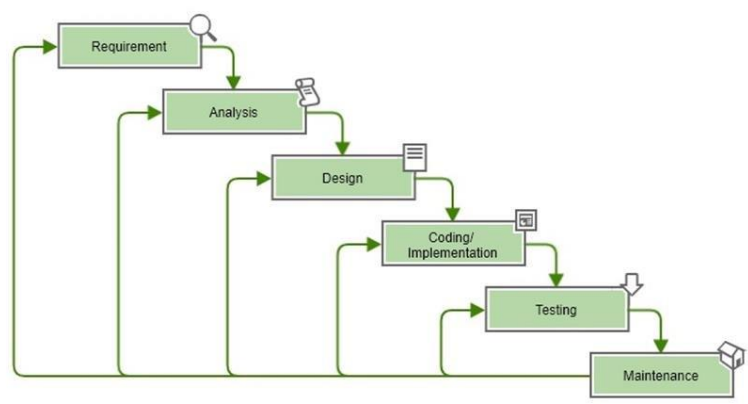

Sumber: (Widiaty et al., 2019)

Gambar 1. Model Waterfall

Pertama Melakukan analisa kebutuhan (Requirements). Proses yaitu melakukan wawancara terhadap narasumber dalam hal ini mengumpulkan data dari user, mengidentifikasi segala kebutuhan yang mendukung proses bisnis yang dijalankan oleh user. Kemudian setelah semua data terkumpul kemudian dianalisa untuk diterjemahkan kedalam Bahasa pemprograman.

Kedua melakukan design System setelah semua data requirement diperoleh secara lengkap kemudian proses penerjemahan dilakukan sebelum menuju proses koding. Fokus kerja pada proses ini bergantung pada beberapa hal, contohnya struktur data, design user interfaces, detail (algoritma), arsitektur perangkat lunak. Tahapan design menghasilkan software documents, dokumen ini digunakan oleh programmer untuk melakukan koding.

Ketiga melakukan coding Proses coding merupakan proses penerjemahan dari user requirement system yang sudah dibuat sedemikian rupa oleh seorang 
analis menjadi software documents, kemudian diterjemahkan lagi menjadi bahasa pemprograman. Tahapan ini merupakan proses yang nyata, dalam artian penggunaan komputer akan digunakan secara maksimal pada tahapan ini. Penggunaan komputer yang dimaksud adalah proses pengkodean dengan Bahasa program untuk kemudian Bahasa program dikemas menjadi sebuah aplikasi yang sesuai dengan user requirements.

Keempat melakukan testing setelah selesai pada proses coding, kemudian dilakukan proses pengetesan dengan tujuan menemukan kesalahan atau biasa dikenal bug fix untuk kemudian diperbaiki. Setelah dinyatakan sudah final dalam hal ini sudah tidak ada bug fix dan perbaikan program sudah selesai, maka program aplikasi sudah bisa digunakan oleh user.

Kelima melakukan implementasi yaitu penerapan aplikasi yang sudah dibuat setelah selesai proses dari mulai user requirements, design, coding, dan testing.

Keeman melakukan maintenance Setiap program aplikasi yang sudah dibuat dan digunakan pasti membutuhkan pemeliharaan dan perubahan. Perubahan biasanya mengikuti perangkat kerja yang digunakan oleh user atau biasanya mengikuti standar operasional kerja yang baru maka aplikasi wajib dilakukan pemeliharaan dan perubahan.

\section{HASIL DAN PEMBAHASAN}

\section{Analisis Sistem Yang Sedang Berjalan}

Laboratorium Dinas Pertanian dan Perikanan Kota Banjarmasin adalah belum adanya sebuah program aplikasi untuk melakukan pengolahan data. Saat ini memang sudah menggunakan komputer sebagai sarana untuk mengerjakan kegiatan-kegiatan yang berkaitan dengan administrasi maupun manajemen. Namun masih sebatas untuk membuat jadwal kunjungan, daftar absensi petugas, pendataan inventaris laboratorium dan membuat laporan dengan menggunakan aplikasi Microsoft Office seperti word dan excel sehingga mengakibatkan keterlambatan dalam pemprosesan data dan menyulitkan dalam pencarian informasi atau data yang diinginkan.

\section{Analisis Sistem Yang di Usulkan}

Usulan sistem baru yang di usulkan oleh penulis berdasarkan temuan permasalahan dan kendalakendala yang di hadapi yaitu merancang dan membuat aplikasi Manajemen laboratorium pada sebuah komputer yang dapat memperbaiki sistem yang ada agar menjadi lebih cepat, tepat, efektif, dan efisien sehingga dapat menanggulangi kendala-kendala dan permasalahan yang ada.

\section{Diagram Konteks}

Diagram konteks adalah diagram yang terdiri dari suatu proses dan menggambarkan ruang lingkup suatu sistem. Diagram konteks merupakan level tertinggi dari DFD yang menggambarkan seluruh input ke sistem atau output dari sistem (Mufizar, 2016).

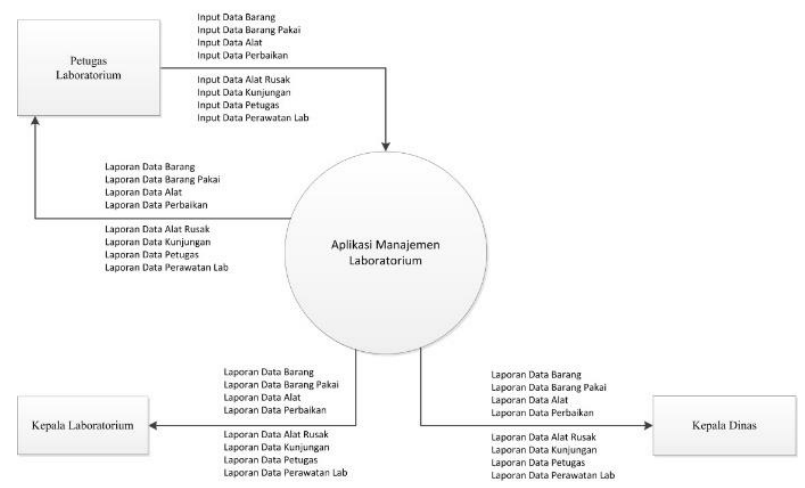

Sumber : (Wiranata et al., 2020) Gambar 2. Diagram Konteks

\section{Data Flow Diagram (DFD)}

DFD menggambarkan penyimpanan data dan proses yang mentransformasikan data. DFD menunjukkan hubungan antara data dan proses pada sistem. Data Flow Diagram dari aplikasi Manajemen Laboratorium adalah sebagai berikut (Suryantara \& Andry, 2018).

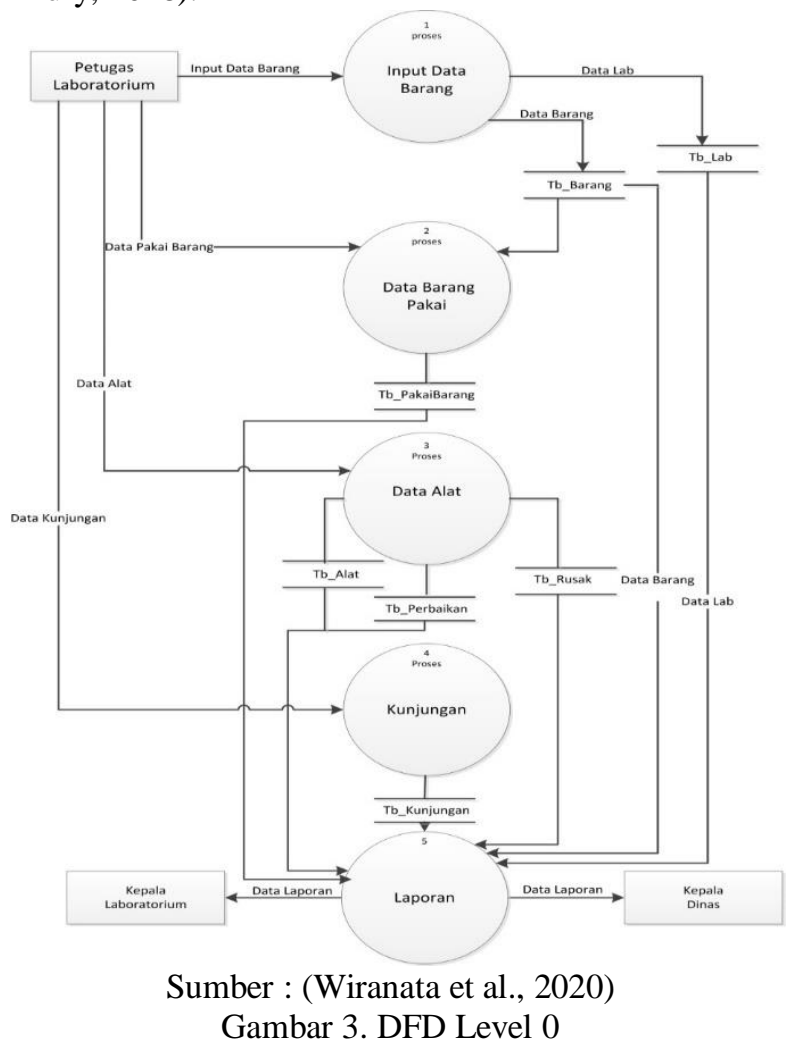




\section{Data Flow Diagram Level 1 Proses Input Data} Barang

Petugas laboratorium menginputkan data barang menghasilkan mengenai data-data barang laboratorium.

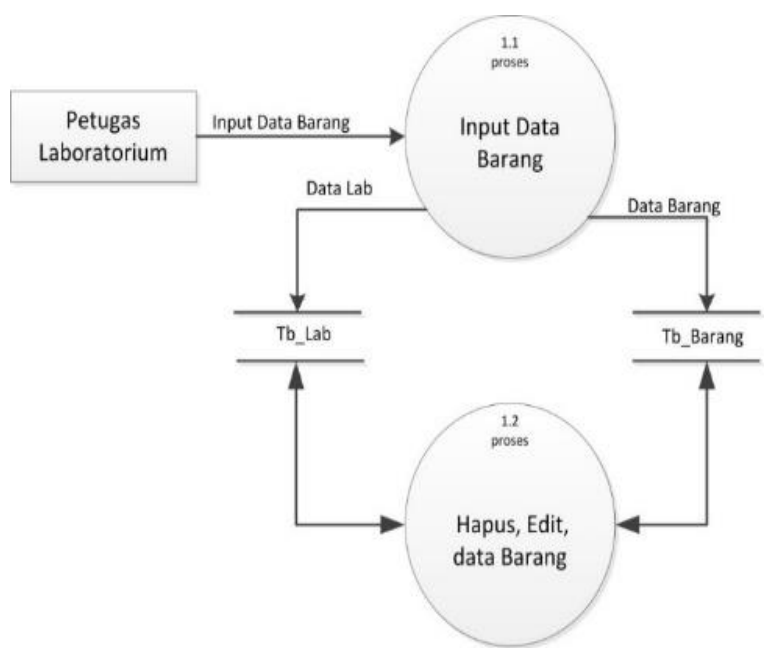

Sumber : (Wiranata et al., 2020)

Gambar 4. DFD level 1 Proses Input Data Barang

Data Flow Diagram Level 1 Proses Input Data Pakai Barang

Petugas laboratorium menginputkan data Pakai barang menghasilkan mengenai data-data Pakai barang laboratorium.

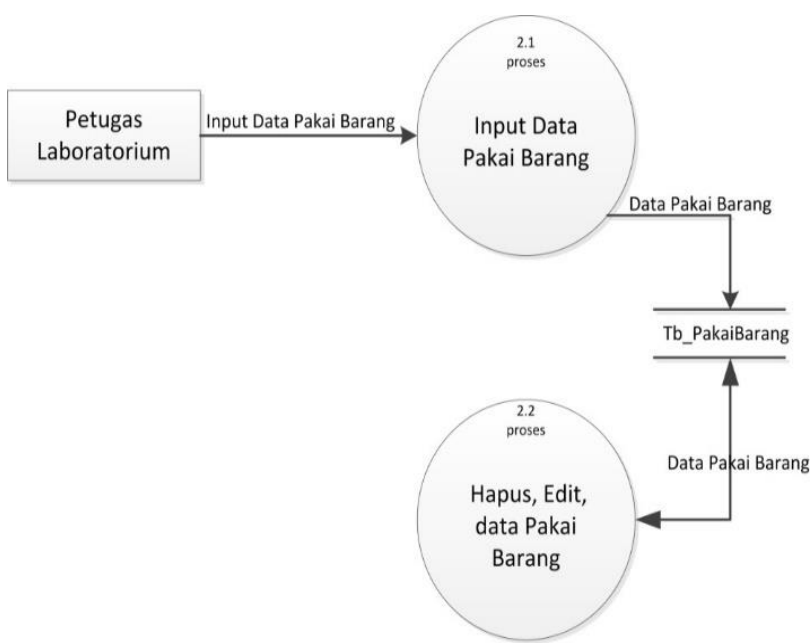

Sumber : (Wiranata et al., 2020)

Gambar 5. DFD Level 1 Proses Input Data Pakai Barang

Data Flow Diagram Level 1 Proses Input Data Alat

Petugas laboratorium menginputkan data alat menghasilkan mengenai data-data alat laboratorium.

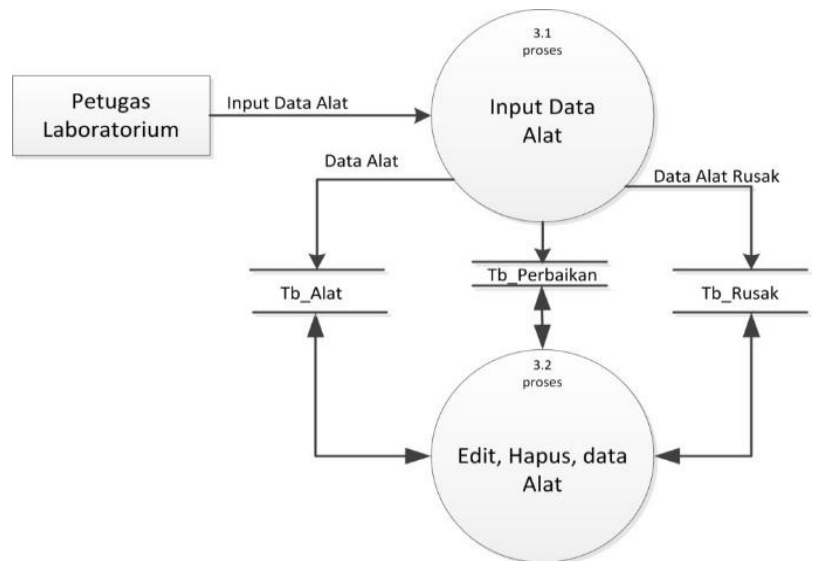

Sumber : (Wiranata et al., 2020)

Gambar 6. DFD Level 1 Proses Input Data Alat

\section{Data Flow Diagram Level 1, Proses Input Data Kunjungan}

Petugas laboratorium menginputkan data kunjungan menghasilkan mengenai data-data kunjungan laboratorium.

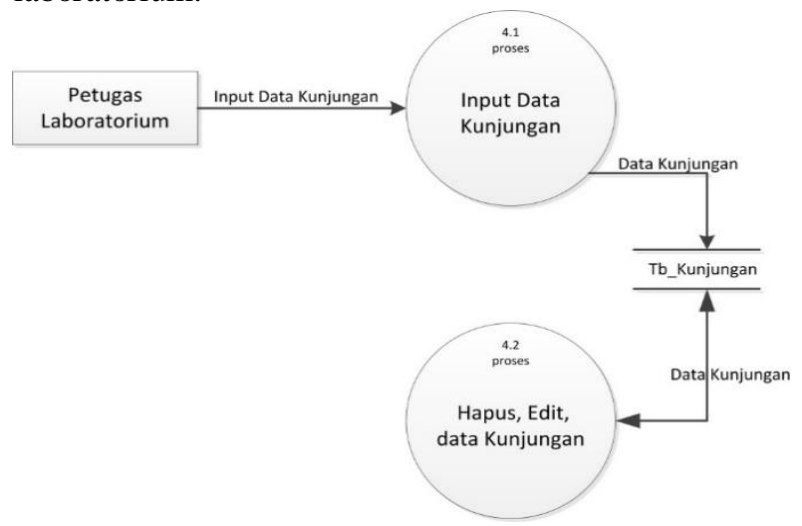

Sumber : (Wiranata et al., 2020)

Gambar 7. DFD Level 1 Proses Input Data Kunjungan

\section{Data Flow Diagram Level 1 Proses 5 Laporan}

Proses ini menghasilkan mengenai data-data Laporan laboratorium yang akan diserahkan ke kepala laboratorium dan kepala dinas.

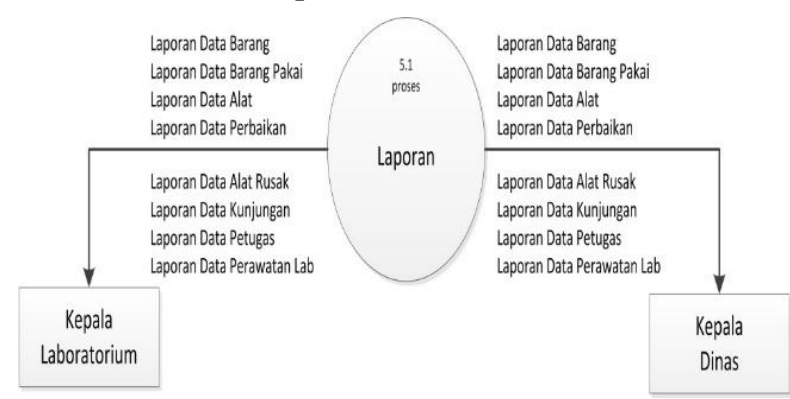

Sumber : (Wiranata et al., 2020)

Gambar 8. DFD Level 1 Proses 5 Laporan 


\section{Class Diagram}

Relasi antar tabel pada aplikasi manajemen laboratorium pada dinas pertanian dan perikanan kota Banjarmasin adalah sebagai berikut : (Harsiti \& Aprianti, 2017).

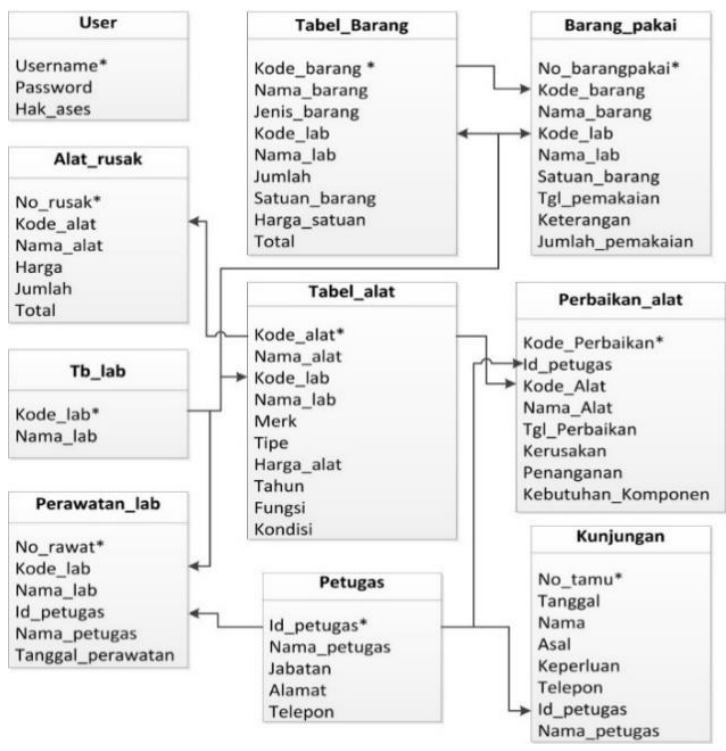

Sumber : (Wiranata et al., 2020)

Gambar 9. Class Diagram

\section{Antar Muka Masukan Sistem}

Implementasi antar muka (user interface implementation) yang dirancang dengan menggunakan bahasa pemograman Delphi 7 pada dinas pertanian dan perikanan kota banjarmasin adalah sebagai berikut :

\section{Form Login}

Form ini digunakan untuk login kedalam program. Halaman ini merupakan pengamanan agar tidak semua orang bisa masuk menu utama dengan mengisi username dan password. Prosesnya jika username dan password salah maka proses tidak akan berhasil dan menu utama tidak akan terbuka.

Berikut gambar dari form menu login:

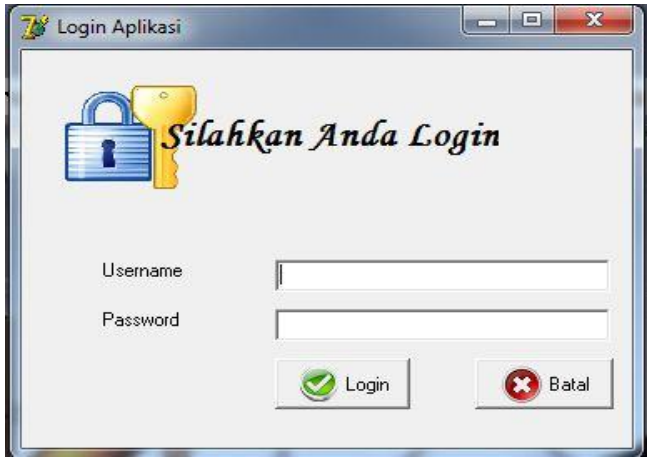

Sumber : (Wiranata et al., 2020)

Gambar 10. Form Menu Login

\section{Form Menu Utama}

Ini merupakan tampilan awal dari form menu utama. Pengguna dapat memilih beberapa menu yaitu: Input data, dan laporan.

Berikut gambar dari form menu Utama:

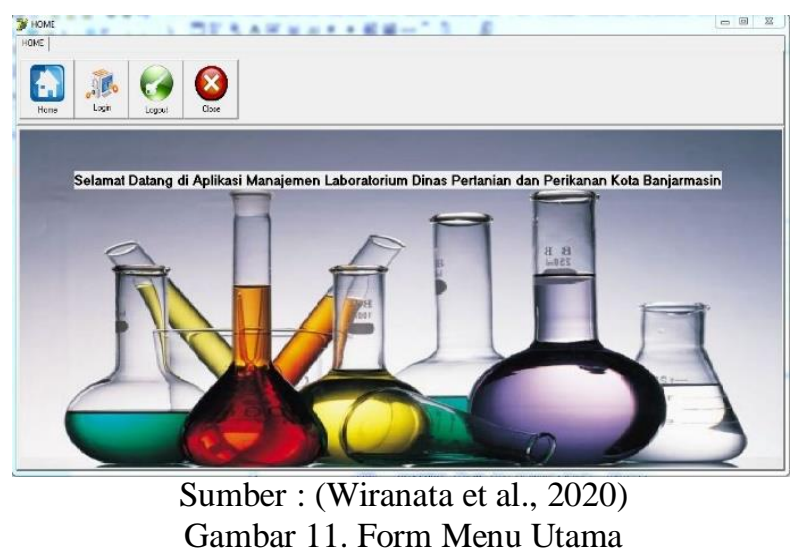

\section{Form Data Barang}

Form ini adalah form untuk menginputkan data barang seperti: kode barang, nama barang, jenis barang, kode lab, nama lab, jumlah, satuan barang, harga satuan, total. Dan disana terdapat beberapa tombol proses seperti tombol simpan, edit, hapus, batal, keluar dan cari.

Berikut gambar dari form Data Barang dari aplikasi manajemen laboratorium pada dinas pertanian dan perikanan kota Banjarmasin :

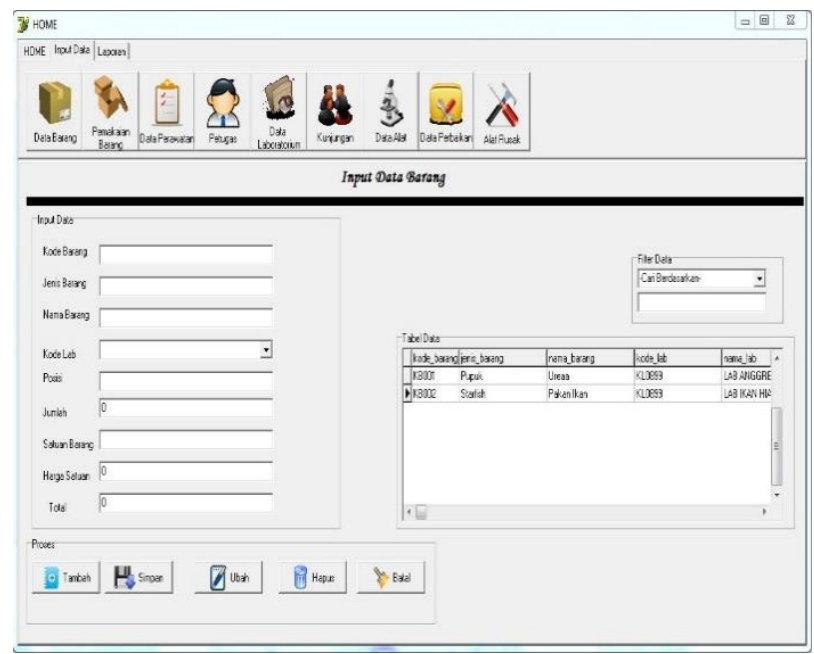

Sumber : (Wiranata et al., 2020)

Gambar 12. Form Data Barang

\section{Form Alat}

Form ini adalah form untuk menginputkan data alat seperti: kode alat, nama alat, kode lab, nama lab merk, type, tahun, kondisi dan fungsi. Dan disana terdapat beberapa tombol proses seperti tombol simpan, edit, hapus, batal, keluar dan cari. 
Berikut gambar dari form Alat dari aplikasi manajemen laboratorium pada dinas pertanian dan perikanan kota banjarmasin:

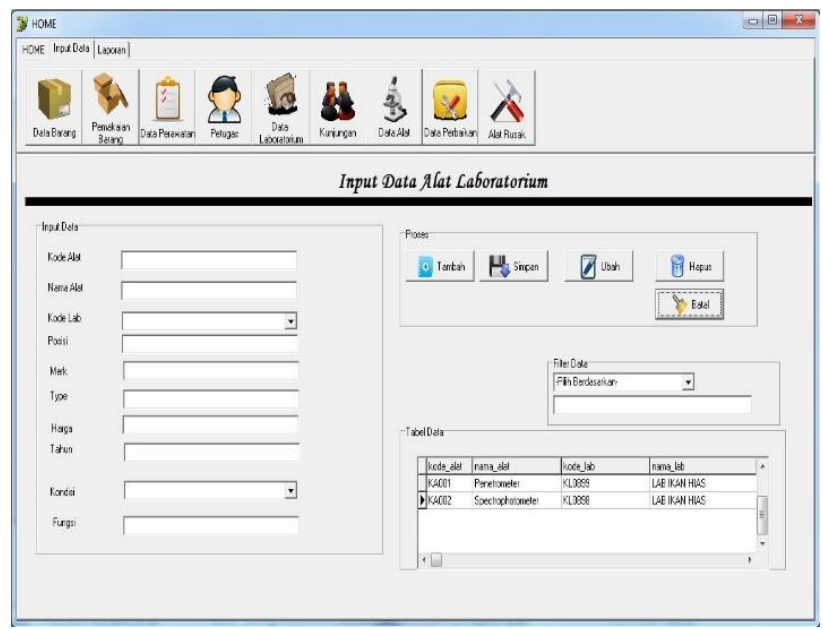

Sumber : (Wiranata et al., 2020)

Gambar 13. Form Alat

\section{Form Perbaikan}

Form ini adalah form untuk menginputkan data perbaikan seperti: kode perbaikan, id petugas, kode alat, nama alat, tanggal perbaikan, kerusakan, penanganan, kebutuhan komponen. Dan disana terdapat beberapa tombol proses seperti tombol simpan, edit, hapus, batal, keluar dan cari.

Berikut gambar dari form Perbaikan dari aplikasi manajemen laboratorium pada dinas pertanian dan perikanan kota Banjarmasin :

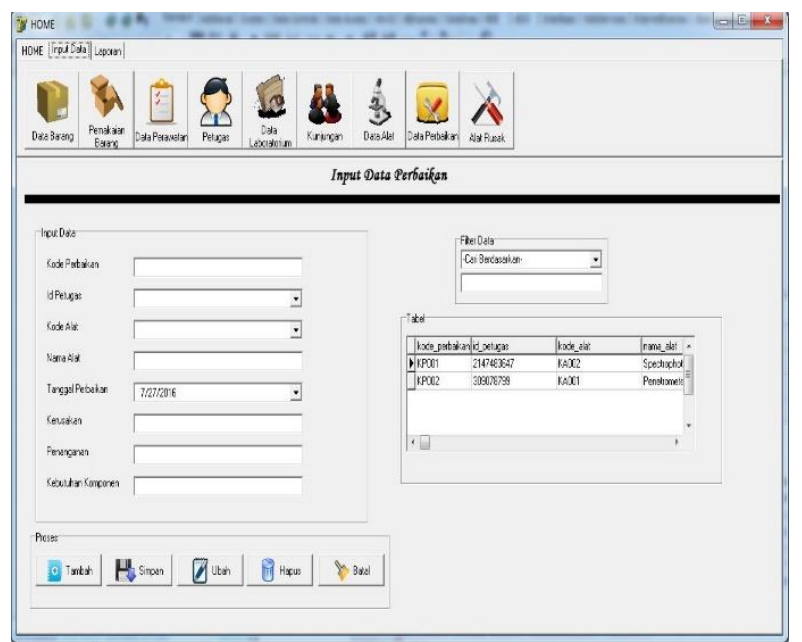

Sumber : (Wiranata et al., 2020)

Gambar 14. Form Perbaikan

\section{Form Lab}

Form ini adalah form untuk menginputkan data lab seperti: kode lab dan nama lab. Dan disana terdapat beberapa tombol proses seperti tombol simpan, edit, hapus, batal, keluar dan cari.

Berikut gambar dari form lab dari aplikasi manajemen laboratorium pada dinas pertanian dan perikanan kota banjarmasin:

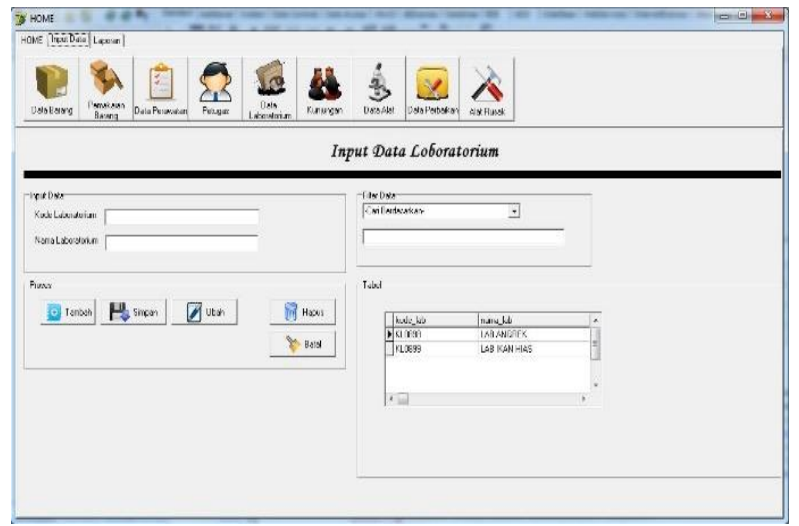

Sumber : (Wiranata et al., 2020)

Gambar 15. Form Lab

\section{Tahapan Pengujian}

Pada tahapan pengujian ini menggunakan aplikasi blackbox. Pada proses ini meliputi proses input atau output (Mustaqbal et al., 2015).

\section{Pengujian Login}

Pengujian form login digunakan untuk memastikan apakah hasil input sesuai dengan hasil output yang di inginkan sehinga admin bisa masuk kedalam sistem informasi ini.

Tabel 1. Pengujian Login

\begin{tabular}{|c|c|c|c|}
\hline $\begin{array}{c}\text { Data } \\
\text { Masukan }\end{array}$ & $\begin{array}{l}\text { Hasil Yang } \\
\text { Diharapkan }\end{array}$ & Pengamat & Hasil \\
\hline $\begin{array}{l}\text { Username } \\
\text { dan }\end{array}$ & $\begin{array}{l}\text { Dengan proses } \\
\text { memasukan }\end{array}$ & $\begin{array}{l}\text { User dapat } \\
\text { login }\end{array}$ & \\
\hline $\begin{array}{l}\text { password } \\
\text { yang } \\
\text { Sesuai }\end{array}$ & $\begin{array}{l}\text { usenamer dan } \\
\text { password bisa } \\
\text { menjalankan } \\
\text { program }\end{array}$ & & Sesuai \\
\hline
\end{tabular}

Sumber : (Wiranata et al., 2020)

\section{Pengujian Data Barang}

Pengujian form data barang digunakan untuk memastikan fungsi, simpan, edit dan hapus data bisa digunakan. 
Tabel 2. Pengujian Data Barang

\begin{tabular}{|c|c|c|c|}
\hline $\begin{array}{c}\text { Data } \\
\text { masukan }\end{array}$ & $\begin{array}{l}\text { Hasil yang } \\
\text { diharapkan }\end{array}$ & Pengamat & Hasil \\
\hline $\begin{array}{l}\text { Input } \\
\text { data } \\
\text { barang }\end{array}$ & $\begin{array}{l}\text { Proses } \\
\text { Penambahan } \\
\text { data barang } \\
\text { berhasil }\end{array}$ & $\begin{array}{l}\text { Data } \\
\text { berhasil } \\
\text { disimpan }\end{array}$ & Sesuai \\
\hline $\begin{array}{l}\text { Input } \\
\text { alamat }\end{array}$ & $\begin{array}{l}\text { Proses ubah } \\
\text { data berhasil }\end{array}$ & $\begin{array}{l}\text { Data } \\
\text { berhasil } \\
\text { diubah }\end{array}$ & Sesuai \\
\hline $\begin{array}{l}\text { Input } \\
\text { alamat }\end{array}$ & $\begin{array}{l}\text { Proses hapus } \\
\text { data berhasil }\end{array}$ & $\begin{array}{l}\text { Data } \\
\text { berhasil } \\
\text { dihapus }\end{array}$ & Sesuai \\
\hline
\end{tabular}

Sumber : (Wiranata et al., 2020)

\section{Pengujian Alat}

Pengujian form alat digunakan untuk memastikan fungsi, simpan, edit dan hapus data bisa digunakan.

Tabel 3. Pengujian Alat

\begin{tabular}{clll}
\hline $\begin{array}{c}\text { Data } \\
\text { masukan }\end{array}$ & $\begin{array}{l}\text { Hasil yang } \\
\text { diharapkan }\end{array}$ & Pengamat & Hasil \\
\hline Input alat & $\begin{array}{l}\text { Proses } \\
\text { Penambahan } \\
\text { data alat } \\
\text { berhasil }\end{array}$ & $\begin{array}{l}\text { Data } \\
\text { berhasil } \\
\text { disimpan }\end{array}$ & Sesuai \\
Input & $\begin{array}{l}\text { Proses ubah } \\
\text { data berhasil }\end{array}$ & $\begin{array}{l}\text { Data } \\
\text { berhasil } \\
\text { diubah }\end{array}$ & Sesuai \\
harga & $\begin{array}{l}\text { Droses } \\
\text { hapus data } \\
\text { herhasil }\end{array}$ & $\begin{array}{l}\text { Derhasil } \\
\text { berha } \\
\text { dihapus }\end{array}$ & Sesuai \\
& & & \\
\hline
\end{tabular}

Sumber : (Wiranata et al., 2020)

\section{Pengujian Perbaikan}

Pengujian form Perbaikan digunakan untuk memastikan fungsi, simpan, edit dan hapus data bisa digunakan.

Tabel 4. Pengujian Perbaikan

\begin{tabular}{llll}
\hline $\begin{array}{c}\text { Data } \\
\text { masukan }\end{array}$ & $\begin{array}{l}\text { Hasil yang } \\
\text { diharapkan }\end{array}$ & Pengamat & Hasil \\
\hline $\begin{array}{l}\text { Input } \\
\text { Perbaikan }\end{array}$ & $\begin{array}{l}\text { Proses } \\
\text { Penambahan } \\
\text { data } \\
\text { perbaikan } \\
\text { berhasil }\end{array}$ & $\begin{array}{l}\text { Data } \\
\text { berhasil } \\
\text { disimpan }\end{array}$ & Sesuai \\
& & \\
\end{tabular}

$\begin{array}{llll}\begin{array}{l}\text { Input } \\ \text { Kerusakan }\end{array} & \begin{array}{l}\text { Proses ubah } \\ \text { data berhasil }\end{array} & \begin{array}{l}\text { Data } \\ \text { berhasil } \\ \text { diubah }\end{array} & \text { Sesuai } \\ \begin{array}{l}\text { Input } \\ \text { Kerusakan }\end{array} & \begin{array}{l}\text { Proses } \\ \text { hapus data } \\ \text { berhasil }\end{array} & \begin{array}{l}\text { Data } \\ \text { berhasil } \\ \text { dihapus }\end{array} & \text { Sesuai } \\ & & \end{array}$

Sumber : (Wiranata et al., 2020)

\section{Hasil Pengujian}

Berdasarkan hasil pengujian dengan kasus sample uji diatas dapat ditarik kesimpulan bahwa pada proses pengisian data pada setiap form dapat dilakukan dengan sukses serta secara sistem dapat menghasilkan output yang diharapkan.

\section{KESIMPULAN}

Berdasarkan hasil penelitian dan pembahasan dalam bab-bab sebelumnya, penulis dapat menarik kesimpulan yaitu: Sistem informasi yang sudah terkomputerisasi dapat memberikan kemudahan serta mempercepat pengolahan data Laboratorium pada Dinas Pertanian dan Perikanan Pemerintah Kota Banjarmasin. Informasi output data yang di sajikan berupa laporan menjadi lebih akurat dan tingkat ketelitian lebih tinggi, sehingga kemungkinan kesalahan sangat kecil. Sistem informasi yang sudah terkomputerisasi dapat memberikan keamanan dalam penyimpanan data sehingga tidak perlu khawatir data menjadi rusak atau hilang.

\section{DAFTAR PUSTAKA}

Ade Davy Wiranata, Hafid Sulistyo Rachman, Y. S. (2020). Penerapan Aplikasi Manajemen Laboratorium Pada Dinas Pertanian Dan Perikanan Kota Banjarmasin.

Ade Davy Wiranata, \& Irwansyah, Agus Budiyantara, A. S. (2020). Employee Candidate Selection Using the Saw and Topsis. 3(1), 22-35.

Agus Budiyantara, Irwansyah, Egi Prengki, P. A. P. (2020). Komparasi Algoritma Decision Tree, Naive Bayes Dan K-Nearest Neighbor Untuk Memprediksi Mahasiswa Lulus Tepat Waktu.

Association, A. L. (1983). ALA Glossary of Library and Information Science. ALA.

Galih Surono, N. N. P. (2020). Sistem Pendukung Keputusan Penentuan Siswa Teladan Menggunakan Metode Simple Additive Weighting (SAW) Studi Kasus : SD BHAKTI YKKP. 
Harsiti, H., \& Aprianti, H. (2017). Sistem Pendukung Keputusan Pemilihan Smartphone dengan Menerapkan Metode Simple Additive Weighting (SAW). JSiI (Jurnal Sistem Informasi), 4, 19-24. https://doi.org/10.30656/jsii.v4i0.372

Mufizar, T. (2016). Sistem Pendukung Keputusan Pemilihan Dosen Berprestasi Di STMIK Tasikmalaya Menggunakan Metode Simple Additive Weighting (SAW). CSRID (Computer Science Research and Its Development Journal), 7(3), 155. https://doi.org/10.22303/csrid.7.3.2015. 155-166

Mustaqbal, M. S., Firdaus, R. F., \& Rahmadi, H. (2015). Pengujian Aplikasi Menggunakan Black Box Testing Boundary Value Analysis (Studi Kasus: Aplikasi Prediksi Kelulusan SNMPTN). I(3), 3136.

Pusparini, N. N., Budiyantara, A., \& Lusa, S. (2020). Pengaruh Knowledge Management System Untuk Jenjang Jabatan. 4(1), 80-88.
Sani, A., \& Wiliani, N. (2019). Faktor Kesiapan Dan Adopsi Teknologi Informasi Dalam Konteks Teknologi Serta Lingkungan Pada Umkm Di Jakarta. JITK (Jurnal Ilmu Pengetahuan Dan Teknologi Komputer), 5(1), 49-56. https://doi.org/10.33480/jitk.v5i1.616

Suryantara, I. G. N., \& Andry, J. F. (2018). Development of Medical Record With Extreme Programming SDLC. International Journal of New Media Technology, 5(1), 47-53. https://doi.org/10.31937 /ijnmt.v5i1.706.

Widiaty, I., Riza, L. S., Ana, Abdullah, A. G., Abdullah, M., \& Mubaroq, S. R. (2019). Web-based digital learning application of iconic batik in batik learning at vocational high school. Journal of Engineering Science and Technology, 14(5), 2475-2484. 